\title{
COMMUNICATION
}

\section{THE ROLE OF SUGAR CANE STRAW ON SOIL REACTION}

\author{
O papel da palha da cana de açúcar na reação do solo
}

\author{
Roberto Antunes Fioretto ${ }^{1}$, Cristine Elizabeth Alvarenga Carneiro ${ }^{2}$, Marcos Antonio Pavan ${ }^{3}$, \\ Conrado Cagliari Fioretto ${ }^{4}$, Leonardo Theodoro Büll ${ }^{5}$
}

\begin{abstract}
Two laboratory experiments were carried out to evaluate the effects of sugar cane straw on soil acidity. Sugar cane straw residues were added on the surface of a Typic Harplortox in a polyvinyl chlorid (PVC) column at rates of 0, 20, 40, and $76 \mathrm{~g} \mathrm{~kg}^{-1}$, the soil was incubated to field capacity with distilled water and incubated for $0,7,14,45$, and 90 days. Soil samples were taken at $0-5$, 5-10, 10-15, 15-20, and 20-25 cm depth. With the increase of sugar cane straw rates one verified the increase of soil $\mathrm{pH}_{\mathrm{Cacl}}$, and decrease of $\mathrm{KCl}$ exchangeable $\mathrm{Al}$ in the top $15 \mathrm{~cm}$ soil layer. The contribution of organic compounds to $\mathrm{Al}$ detoxification incresead with increasing sugar cane straw rates. Wheat root elongation used as acid indicator plant increased with increasing sugar cane straw rates. Maximum root growth was about $15 \mathrm{~cm}$ long in the soil after eight days for the highest sugar cane straw rate.
\end{abstract}

Index terms: Saccarum sp., plant residue, aluminun.

\section{RESUMO}

Conduziram-se dois experimentos em laboratório avaliar o efeito da palha da cana- de-açúcar na acidez do solo. A palha da cana foi adicionada nas doses de $0,20,40$, e $76 \mathrm{~g} \mathrm{~kg}^{-1}$ na superfície de um latossolo roxo distrófico acondicionado em colunas de PVC. O solo foi incubado a capacidade de campo durante $0,7,14,45$, e 90 dias. Após cada incubação, o solo das colunas foram subdividido e amostrado nas seguintes frações $0-5,5-10,10-15,15-20$, e 20-25 cm. Com o aumento da dose da palha da cana verificou-se aumento do $\mathrm{pH}_{\mathrm{CaCl2}}$ do solo e decréscimo do alumínio trocável até a camada de $15 \mathrm{~cm}$ de solo da coluna de PVC. A contribuição de compostos orgânicos para a destoxificação do $\mathrm{Al}$ aumentou com o acréscimo das doses da palha da cana. $\mathrm{O}$ crescimento da raiz das plantas trigo usadas como planta indicadora aumentou com o acréscimo das doses da palha de cana. O máximo de crescimento da raiz foi até a camada de $15 \mathrm{~cm}$ de solo depois de oito dias para a maior dose de palha da cana-de-açúcar.

Termos para indexação: Saccarum sp., resíduo vegetal, alumínio, $\mathrm{pH}$ do solo.

\section{(Received in november 8, 2007 and approved in july 10, 2008)}

Burning sugar cane straw before harvesting is a common practice in Brazil. However, a new brazilian legislation has been introduced to reduce burning sugar cane and improve mechanical harvesting. It is estimated that sugar cane residues left after mechanical harvesting varied from $13.8 \mathrm{Mg} \mathrm{ha}^{-1} \mathrm{y}^{-1}$ dray matter (OLIVEIRA et al., 1999) to $45 \mathrm{Mg} \mathrm{ha}^{-1} \mathrm{y}^{-1}$ fresh matter (ASGHAR \& KANEHIRO, 1976).

Although there are many questions about the mangement of the sugar cane straw left after mechanical harvesting, the greatest impact compared with burning will be on the soil organic matter content and its implication with soil chemical, physical, and biological properties
(MENDONZA et al., 2002). It is well stablished that organic matter has great effect on acid soil chemistry (ASGHAR \& KANEHIRO, 1980; HUE, 1992; MEDA et al., 2001; MIYAZAWA et al., 1993; POCKNEE \& SUMNER, 1997). Many mechanisms have been suggested to explain the acid neutralizing capacity of the organic matter, such as: $\mathrm{H}^{+}$ion adsorption on the surface of organic matter (HOYT \& TURNER, 1975); exchangeable reaction between soil $\mathrm{OH}^{-}$ with organic anion (HUE \& AMIEN, 1989); and reduction reactions envolving N-cycling (HOYT \& TURNER, 1975; HUE, 1992). Recent reports have found that plant materials with high basic cation contents are more efficient in neutralizing soil acidity than those with low contents

\footnotetext{
1Engenheiro Agrônomo, Doutor - Centro de Ciências Agrárias/CCA, Departamento de Agronomia - Universidade Estadual de Londrina/UEL - Rod Celso Garcia Cid - Cx. P. 6001 - 86051-990 - Londrina, PR - roberto@laborsolo.com.br

${ }^{2}$ Química, Doutora - Departamento de Pesquisa e Desenvolvimento - Laborsolo do Brasil - Av. Tiradentes, 3173 - Jardim Jockey Club - $86072-000$ Londrina, PR - cristine@laborsolo.com.br

${ }^{3}$ Engenheiro Agrônomo, PhD - Área de Solos - Instituto Agronômico do Paraná/IAPAR - Rod. Celso Garcia Cid, Cx. P.481 - 86001-901 - Londrina, PR mpavan@iapar.br

${ }^{4}$ Universidade Estadual de Londrina/UEL - Cx. P. 6001 - 86051-990

${ }^{5}$ Engenheiro Agrônomo, PhD - Departamento de Recurso Naturais - Universidade Estadual Paulista "Júlio de Mesquita Filho" Faculdade de Ciências Agronômicas/UNESP - Faz. Experimental Lageado, R. José Barbosa de Barros, 1780 Lageado - 18610-307 - Cx. P. 237 -Botucatu, SP - bull@pq.cnpq.br
} 
(MIYAZAWA et al., 1993; POCKNEE \& SUMNER, 1997). In fact, Cassiolato et al. (2002) showed that there is a linear relationship between soil $\mathrm{pH}$ and plant residue basic cation content. However, it is accepted that the quality of the organic matter measured as its total basic cations is very important in the amelioration of soil acidity (MEDA et al., 2001; SUMNER \& PAVAN, 2000). The aim of this study was to evaluate the influence of sugar cane straw on soil acidity and on wheat root elongation used as test plant.

Sugar cane straw composed by stem and leaves (Saccarum sp., RB85-5536 variety) was collected in the field at Usina de Açucar \& Alcool - Cooperativa Agropecuária de Rolândia (COROL), in Rolândia, state of Paraná, Brazil. Plant materials were dried at $65^{\circ} \mathrm{C}$ for $48 \mathrm{~h}$, ground to pass $1 \mathrm{~mm}$ sieve, stored in paper boxes, and then used for the following chemical analysis: plant nutrient contents (MIYAZAWA et al., 1992); basic cation excess (PIERRE \& BANWART, 1973); acidity neutralizing capacity (MIYAZAWA et al., 1993); and $\mathrm{H}^{+}$adsorption capacity using a titration curve (YOUNG et al., 1981). The plant extract was obtained using the procedure described by Meda et al. (2001) and analyzed.

Soil samples taken from the $0-25 \mathrm{~cm}$ depth of a Typic Harplortox (U.S. Soil Taxonomy) were air dried, ground and passed through a $2 \mathrm{~mm}$ sieve. The soil had an original $\mathrm{pH}_{\mathrm{CaCl} 2}$ value of 4.1 ; exchangeable $\mathrm{Ca}, \mathrm{Mg}, \mathrm{K}$, and $\mathrm{Al}$ contents of 1.04, $0.43,0.46$, and $2.2 \mathrm{cmol} \mathrm{dm}^{-3}$, respectively, and total organic carbon content of $10.8 \mathrm{~g} \mathrm{~kg}^{-1}$. The clay, silt, and sand contents were: $787.2,65.2$, and $147.6 \mathrm{~g} \mathrm{~kg}^{-1}$, respectively. Columns $\left(305 \mathrm{~cm}^{3}\right)$ of rigid polyvinyl chlorid (PVC) were used. Soil samples were transferred to PVC columns and compacted to a homogeneous bulk density (mean of $1.0 \mathrm{~g} \mathrm{~cm}^{-3}$ ). The sugar cane straw $(1 \mathrm{~mm}$ sieve) was added on the soil surface at rates of $0,20,40$, and $76 \mathrm{~g} \mathrm{~kg}$ ${ }^{1}$ of soil. These rates were added at the amount equivalent to neutralize $\mathrm{KCl}$ exchangeable $\mathrm{Al}(0.6,1.3$, and $2.5 \mathrm{cmol}$ $\left.\mathrm{dm}^{-3}\right)$. The soil columns were brought to field capacity with distilled water and incubated for 0 (initial), 7, 14, 45, and 90 days. At each time, deionized water was added in as amount equivalent to four porous volumes ( $122 \mathrm{~mL}$ per column) at a rate of $0.5 \mathrm{ml} \mathrm{min}^{-1}$. Soil samples were taken at $0-5,5-10$, $10-15,15-20$, and $20-25 \mathrm{~cm}$ depth, air dried, ground to pass a $2 \mathrm{~mm}$ sieve, and analyzed for $\mathrm{pH}_{\mathrm{CaCl}_{12}}\left(0.01 \mathrm{~mol} \mathrm{~L}^{-1} \mathrm{CaCl}_{2}\right.$ suspension, 1:2.5 soil solution ratio, $1 \mathrm{~h}$ shaking time); $\mathrm{KCl}$ exchangeable $\mathrm{Al}\left(1 \mathrm{~mol} \mathrm{~L}^{-1} \mathrm{KCl}, 1: 10\right.$ soil: solution ratio); and $\mathrm{CuCl}_{2}$ exchangeable $\mathrm{Al}$ (OLIVEIRA et al., 1997). Al$\mathrm{KCl}$ was assumed to be exchangeable inorganic $\mathrm{Al} ; \mathrm{Al}-$ $\mathrm{CuCl}_{2}$ total exchangeable $\mathrm{Al}$ (organic + inorganic); and (Al$\left.\mathrm{CuCl}_{2}\right)$ - $(\mathrm{Al}-\mathrm{KCl})$ exchangeable organic $\mathrm{Al}$.
A biological test was evaluated to verify the capacity of sugar cane extract on acid soil amelioration and on root elongation using wheat (Anahuac cultivar) as indicator plant. The biological test was the same described by Franchini et al. (2001). All treatments have three replicates in a completly randomized block design.

Sugar cane straw presented the following chemical properties: organic carbon $610 \mathrm{~g} \mathrm{~kg}^{-1}$; total nitrogen 71.4 cmol kg ; base excess $200 \mathrm{cmol} \mathrm{kg}^{-1}$; total basic cations $(\mathrm{Ca}+\mathrm{Mg}+\mathrm{K}) 81.2 \mathrm{cmol} \mathrm{kg}^{-1}$; and hidrogen neutralizing capacity $33 \mathrm{cmol} \mathrm{kg}^{-1}$. In according with Pierre \& Banwart (1973) sugar cane straw is classified as high potential in alleviating soil acidity due to its high base excess content. The results also show that for each $100 \mathrm{cmol} \mathrm{kg}^{-1}$ of $\mathrm{N}$ absorbed by sugar cane roots there is a base excess of 280 $\mathrm{cmol} \mathrm{kg}{ }^{-1}$. Thus, this sugar cane straw present higher cation contents than inorganic anion contents. If the electrical neutrality principle is required, the excess of cation must be balanced with organic anions. In fact, there is a good correlation between base excess and organic anions in plant tissues (DEWIT et al., 1963).

The quality of sugar cane straw measured as its acid neutralizing capacity was an important residue in the amelioration of soil acidity after 90 days of incubation (Table 1). Increasing sugar cane straw rates increased $\mathrm{pH}_{\mathrm{CaCl2}}$ and organic carbon up to $15 \mathrm{~cm}$ soil depth and decreased $\mathrm{KCl}$ exchangeable acidity (H+Al) up to $25 \mathrm{~cm}$ soil depth. These results confirm the high acidity neutralizing capacity of sugar cane straw based as its high base excess content.

Figure 1 shows the effect of sugar cane on soil $\mathrm{pH}_{\mathrm{CaC12}}$ as functions of rates, soil depth, and incubation time. Soil $\mathrm{pH}_{\mathrm{CaCl} 2}$ increased with increasing sugar cane rates mainly in the first 7 days incubation and then decreased with increasing time. These effects were more evident in the $0-10 \mathrm{~cm}$ soil depth. Similar results were obtained by Miyazawa et al. (1993) and Pocknee \& Sumner (1997) on brazilian and north american soils, respectively with different plant materials. There are at least two effects on soil $\mathrm{pH}$ : first (short time effect, 7 days) a rapid $\mathrm{pH}$ increase due to mineralization of basic cations in the organic material, high base excess, low N/basic cation ratio and high $\mathrm{H}^{+}$adsorption on the functional groups of the organic compounds $\left(\mathrm{RCOO}^{-}+\mathrm{H}^{+} \rightarrow \mathrm{RCOO}^{-} \mathrm{H}^{+}\right)$; and second (medium time effect) $\mathrm{pH}$ increases due to the organic matter mineralization, where lime is liberated in proportion to the basic cation content (POCKNEE \& SUMNER, 1997). 
Table 1 - Effect of sugar cane straw rates on soil acidity and organic carbon contents as function of soil depth at 90 days incubation time.

\begin{tabular}{|c|c|c|c|c|c|}
\hline $\begin{array}{l}\text { Soil depth } \\
\quad(\mathrm{cm})\end{array}$ & $\begin{array}{c}\text { Sugar cane } \\
\text { Rates }\end{array}$ & $\mathrm{pH}_{\mathrm{CaCl} 2}$ & $\mathrm{KCl}-\mathrm{Al}$ & $\begin{array}{c}\text { Total acidity } \\
(\mathrm{H}+\mathrm{Al})\end{array}$ & $\begin{array}{l}\text { Organic } \\
\text { Carbon }\end{array}$ \\
\hline \multirow{6}{*}{$0-5$} & $\left(\mathrm{~g} \mathrm{~kg}^{-1}\right)$ & \multicolumn{3}{|c|}{$\left(\mathrm{cmol} \mathrm{dm}{ }^{-3}\right)$} & $\left(\mathrm{g} \mathrm{dm}^{-3}\right)$ \\
\hline & 0 & 3.8 & 2.35 & 10.42 & 12.8 \\
\hline & 20 & 4.4 & 0.73 & 7.04 & 13.8 \\
\hline & 40 & 5.0 & 0.23 & 5.49 & 14.8 \\
\hline & 76 & 5.6 & 0.00 & 4.14 & 15.9 \\
\hline & 0 & 3.9 & 2.34 & 10.35 & 12.7 \\
\hline \multirow{3}{*}{$5-10$} & 20 & 4.0 & 1.94 & 9.36 & 13.2 \\
\hline & 40 & 4.2 & 1.15 & 7.79 & 14.1 \\
\hline & 76 & 4.6 & 0.57 & 6.43 & 14.6 \\
\hline \multirow{4}{*}{$10-15$} & 0 & 3.8 & 2.44 & 10.83 & 12.8 \\
\hline & 20 & 3.8 & 2.37 & 10.43 & 13.0 \\
\hline & 40 & 4.0 & 1.91 & 9.37 & 12.7 \\
\hline & 76 & 4.2 & 1.25 & 7.86 & 13.3 \\
\hline \multirow{4}{*}{$15-20$} & 0 & 3.8 & 2.51 & 10.50 & 12.6 \\
\hline & 20 & 3.8 & 2.39 & 10.20 & 12.7 \\
\hline & 40 & 3.9 & 2.11 & 9.69 & 12.5 \\
\hline & 76 & 4.1 & 1.58 & 8.79 & 12.8 \\
\hline \multirow{4}{*}{$20-25$} & 0 & 3.8 & 2.42 & 10.43 & 12.4 \\
\hline & 20 & 3.9 & 2.31 & 10.42 & 13.3 \\
\hline & 40 & 3.9 & 2.18 & 9.62 & 12.4 \\
\hline & 76 & 4.0 & 1.85 & 9.56 & 13.4 \\
\hline V.C.\% & & 1.80 & 7.83 & 6.00 & 6.06 \\
\hline D.M.S.(1\%) $)^{1}$ & & 0.09 & 0.16 & 0.64 & 0.96 \\
\hline D.M.S.(1\%) & & 0.08 & 0.15 & 0.61 & 0.92 \\
\hline
\end{tabular}

${ }^{1}$ Tukey (Rates)

${ }^{2}$ Tukey (Depth)

Figure 2 shows the effect of sugar cane straw on $\mathrm{KCl}-\mathrm{Al}$ as functions of rates, soil depth, and incubation time. At the top 0-5 cm soil layer, the highest sugar cane straw rate neutralized totally $\mathrm{KCl}-\mathrm{Al}$. Increasing sugar cane rates decreased $\mathrm{KCl}-\mathrm{Al}$, and the effect was higher in the begining of the experiment ( 0 to 7 days) than at the end (90 days) mainly in the top $15 \mathrm{~cm}$ soil layer. These results support the view that complexation of Al by organic compounds is an important reaction for decreasing $\mathrm{Al}$ toxicity [3 R-COO $\mathrm{K}^{+}+\mathrm{Al}^{+++} \rightarrow\left(\mathrm{R}-\mathrm{COO}^{-}\right)_{3} \mathrm{Al}^{+++}+3 \mathrm{~K}^{+}$]. When the $\mathrm{pH}$ is above 5.2, the Al-organic complexes precipitate as $\mathrm{Al}(\mathrm{OH})_{3}$. Sumner \& Pavan (2000) explored the more theoretical aspects of soil acidity amelioration by organic compounds. 
Soil Depth 0 - 5 cm

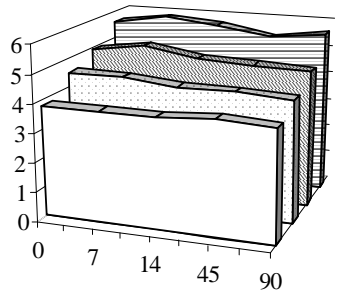

Soil Depth 5 - 10 cm

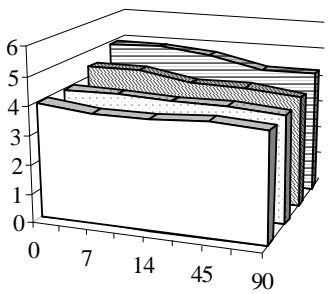

Soil Depth 10 - 15 cm

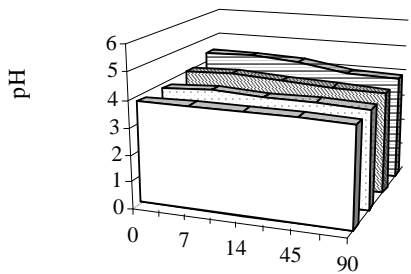

Soil Depth 15 - 20 cm

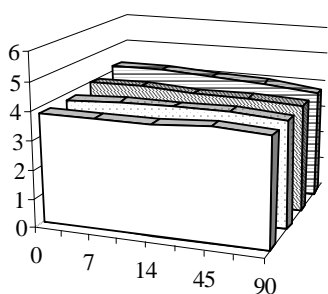

Soil Depth $20-25 \mathrm{~cm}$

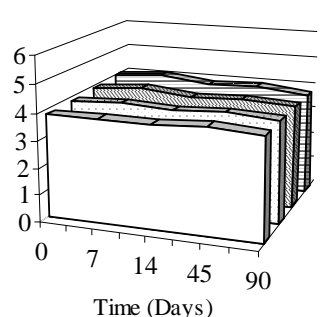

Time (Days)

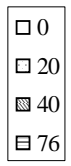

目 76

Figure 1 - Change soil $\mathrm{pH}$ as function of soil depth, sugar cane straw rates $(0,20,40 \mathrm{e} 76) \mathrm{g} \mathrm{kg}^{-1}$ and incubation time.

Soil Depth 0 - 5 cm

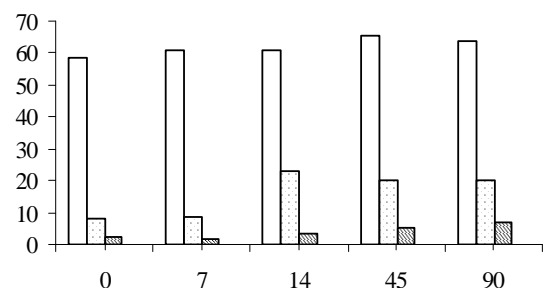

Soil Depth 5 - $10 \mathrm{~cm}$

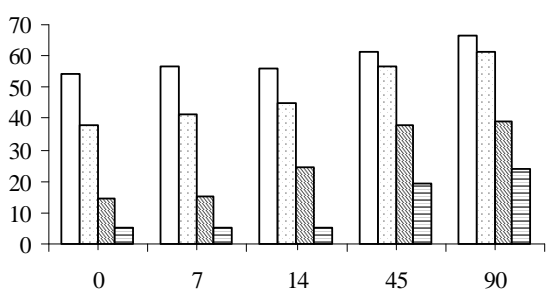

Soil Depth 10 - $15 \mathrm{~cm}$

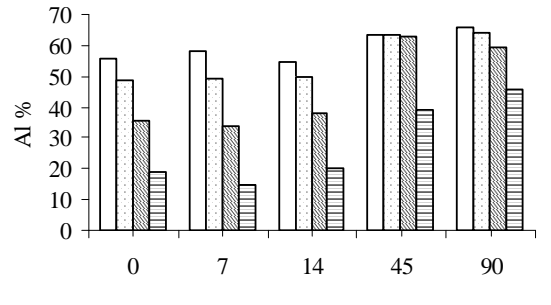

Soil Depth15 - 20 cm
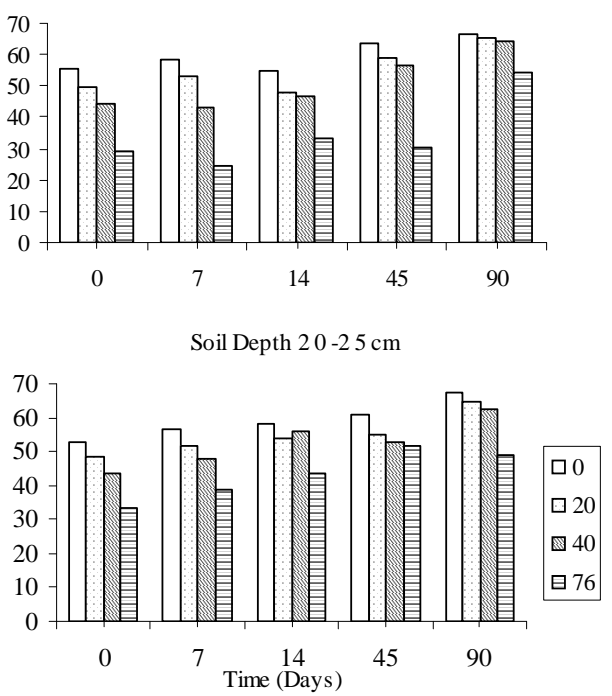

Figure 2 - Change in aluminum contents as function of soil depth, sugar cane straw rates $(0,20,40$ e 76$) \mathrm{g} \mathrm{kg}^{-1}$, and incubation time. 
Table 2 shows the effect of sugar cane straw rates on the contributions of organics and $\mathrm{pH}$ to $\mathrm{Al}$ neutralization in soil profile. The contributions of organics and $\mathrm{pH}$ were calculated as it follows:

$$
\text { Organics }=\frac{\left[\left(\mathrm{Al}-\mathrm{CuCl}_{2}\right)-(\mathrm{Al}-\mathrm{KCl})\right]_{\mathrm{T}}-\left(-\left(\mathrm{Al}-\mathrm{CuCl}_{2}\right)-(\mathrm{Al}-\mathrm{KCl})\right]_{\underline{\mathrm{C}}} \times 100}{(\mathrm{Al}-\mathrm{KCl})_{\mathrm{C}}-(\mathrm{Al}-\mathrm{KCl})_{\mathrm{T}}}
$$

Where $\mathrm{T}=$ treatment and $\mathrm{C}=$ control, and $\mathrm{pH}=100$ organics (\%).

Table 2 - Contributions of organics and $\mathrm{pH}$ to $\mathrm{Al}$ neutralization.

\begin{tabular}{cccc}
\hline \multirow{2}{*}{$\begin{array}{c}\text { Soil depth } \\
(\mathrm{cm})\end{array}$} & $\begin{array}{c}\text { Sugar cane } \\
\text { straw } \\
\text { rates }\left(\mathrm{g} \mathrm{kg}^{-1}\right)\end{array}$ & \multicolumn{2}{c}{ Contributions \% } \\
\cline { 3 - 4 } $0-5$ & 0 & - & $\mathrm{pH}$ \\
& 20 & 41 & 59 \\
$5-10$ & 76 & 32 & 68 \\
& 0 & - & - \\
& 20 & 10 & 90 \\
$10-15$ & 76 & 62 & 38 \\
& 0 & - & - \\
& 20 & 17 & 83 \\
$15-20$ & 76 & 62 & 38 \\
& 0 & - & - \\
& 20 & 0 & 100 \\
$20-25$ & 76 & 72 & 28 \\
& 0 & - & - \\
& 20 & 0 & 100 \\
& 76 & 49 & 51 \\
\hline
\end{tabular}

Increasing sugar cane straw rates from 20 to $76 \mathrm{~g} \mathrm{~kg}^{-1}$ increased the contribution of organics to $\mathrm{Al}$ detoxification up to $20 \mathrm{~cm}$ soil depth. The contribution of organics to $\mathrm{Al}$ neutralization was about $72 \%$ in the $15-20 \mathrm{~cm}$ in soil layer. Thus, when organic strategy is adopted in sugar cane plantation, where all trashes are left on soil surface without burning, the organic compounds form complexes with $\mathrm{Al}$. The contribution of $\mathrm{pH}$ to $\mathrm{Al}$ detoxification increased with decreasing sugar cane straw rates, increasing sugar cane straw rates from 0,20 , to $76 \mathrm{~g} \mathrm{~kg}^{-1}$ increased wheat root elongation (indicator plant) from $3.39,10.26$ to $15.71 \mathrm{~cm}$, respectively after 8 days. As expected, wheat root growth was due to increase soil $\mathrm{pH}$ and decrease $\mathrm{KCl}-\mathrm{Al}$ up to 15 $\mathrm{cm}$ soil depth. Therefore, the organic compounds are important in the transfer of alkalinity from top to subsoil enhancing deeper root elongation.
Table 3 - Sugar cane straw rates in wheat root elongation.

\begin{tabular}{cc}
\hline Rates $\left(\mathrm{g} \mathrm{kg}^{-1}\right)$ & Root elongation $(\mathrm{cm})$ \\
\hline 0 & $3.39 \mathrm{c}$ \\
20 & $10.26 \mathrm{~b}$ \\
76 & $15.71 \mathrm{a}$ \\
\hline
\end{tabular}

Tukey $1 \%$.

The sugar cane straw left on soil surface after harvesting, improves the soil fertility acidity, with the increase of soil bulk explored by sugar cane root, mainly by toxic-Al neutralized.

\section{REFERENCES}

ASGHAR, M.; KANEHIRO, Y. Effects of sugar cane trash and pianeapple residue on soil nitrogem, $\mathrm{pH}$, and redox potencial. Plant and Soil, v. 44, p. 213-223, 1976.

ASGHAR, M.; KANEHIRO, Y. Effectos of sugar cane trash and pianeapple residue on soil $\mathrm{pH}$, redox potential, extractable Al, Fe, and Mn. Tropical Agriculture, v. 57, p. $245-258,1980$.

CASSIOLATO, M. E.; MYIAZAWA, M.; MEDA, A. R.; PAVAN, M. A. A laboratory method to estimate the efficiency of plant extract to neutralize soil acidity.

Brazilian Archives Biology and. Technology, v. 45, n. 2, p. 219-222, 2002.

\section{DEWIT, C. T.; DIJKSHOORN, W.; NAGGLE, J. C. Ionic} balance and growth of plants. Wageningen: Centrum voor landbouw publikaties in landbouw documentatie, 1963. $69 \mathrm{p}$.

FRANCHINI, J. C.; MEDA, A. R.; CASSIOLATO, M. E.; MIYAZAWA, M.; PAVAN, M. A. Potencial de extratos de resíduos vegetais na mobilização do calcário no solo por método biológico. Science Agriculture, v. 58, p. 357360, 2001.

HOYT, P. B.; TURNER, R. C. Effects of organic materials added to a very acid soils on $\mathrm{pH}$, aluminum, exchangeable $\mathrm{NH}_{4}$, and crop yields. Soil Science, v. 119, p. $227-237,1975$.

HUE, N. V. Correcting soil acidity of a higly weathered ultisol with chichen manure and sewage sludge.

Communication Soil Science Plant Analytic, v. 23, p. 241-264, 1992. 
HUE, N. V.; AMIEN, I. Aluminum detoxification with green manures. Commun. Soil Science Plant Analytical, v. 20, p. 1499-1511, 1989.

MEDA, A. R.; CASSIOLATO, M. E.; PAVAN, M. A.; MIYAZAWA, M. Alleviating soil acidity through plant organic compounds. Brazilian Archives Biology and Technology, v. 44, p. 185-189, 2001.

MENDONZA, H. N. S.; LIMA, E.; ANJOS, L. H. C.; SILVA, L. A.; CEDDIA, M. B.; ANTUNES, M. V. M. Propriedades químicas e biológicas de solo de tabuleiro cultivado com cana-de-açúcar com e sem queima da palha. Revista Brasileira de Ciência do Solo, Campinas, v. 24, p. 201-207, 2002.

MIYAZAWA, M.; PAVAN, M. A.; BLOCH, M. F. M. Análise quimica de tecido vegetal. Londrina: IAPAR, 1992. 17 p. (Circular, 74).

MIYAZAWA, M.; PAVAN, M. A.; CALEGARI, A. Efeito de material vegetal na acidez do solo. Revista Brasileira de Ciência do Solo, Campinas, v. 17, p. 411-416, 1993.

OLIVEIRA, C. C.; PAVAN, M. A.; MIYAZAWA, M.; FRANCHINI, J. C. Determinação de aluminio orgânico do solo extraído com $\mathrm{CuCl}_{2}$. Arquives Biology and Technology, v. 40, p. 213-223, 1997.

OLIVEIRA, M. W.; TRIVELIN, P. C. O.; PENATTI, C. P.; PICCOLO, M. C. Decomposição liberação de nutrientes da palha de cana de açúcar em campo. Pesquisa Agropecuária Brasileira, Brasília, v. 34, p. 2359-2362, 1999.

PIERRE, W. H.; BANWART, W. L. Excess-base and excessbase/ nitrogem ratios of various crop species and plant parts. Agronomy Journal, Madison, v. 65, p. 91-96, 1973.

POCKNEE, S.; SUMMER, M. E. Cation and nitrogem contents of organic matter determine its soil lime potential. Soil Science Society American Journal, v. 61, p. 86-92, 1997.

SUMNER, M.; PAVAN, M. A. Alleviating soil acidity through organic matter management. In: SIMPÓSIO ROTAÇÃO SOJA/MILHO NO PLANTIO DIRETO, 2000, Piracicaba, SP. Anais... Piracicaba: Potafos, 2000. CD-ROM.

YOUNG, S. D.; BACHE, B. W.; WELCH, D.; ANDERSON, H. A. Analysis of the potentiometric titration of natural and synthetic polycarboxylates. Soil Science, v. 32, p. 579-592, 1981. 